\title{
312 高温空気燃焼技術を用いた石油燃料の環境低負荷燃焼技術の開発 \\ Development of Low Emission Combustion Technology of Petroleum with High Temperature Air Combustion Technology
}

\author{
O下 种郎、佐藤 正志(石油産業活性化センター)、荒明 但宏(日本ファーネスエ業) \\ 正 伊藤 義人、鶴田 直樹、正 吉川 邦夫(東工大) \\ Nobuo SHIMO, Masashi SATOH, Petroleum Energy Center, \\ Advanced Technology and Research Institute, 1-4-10, Ohnodai, Midori-ku, Chiba \\ Tadahiro ARAAKE, Nippon Furnace Kogyo Kaisya, Ltd. \\ Yoshito ITOH, Naoki TURUTA, Kunio YOSHIKAWA, Tokyo Institute of Technology
}

\begin{abstract}
Combustibility of petroleum was investigated with high temperature air combustion technology. Ultra low NOx emission ( $\sim 10 \mathrm{ppm})$ was achieved both for the kerosene and heavy oil $\mathrm{A}$ as fuels using a $0.4 \mathrm{MW}$ class test furnace. Thermal NOx was extremely reduced as decreasing the air ratio and fuel NOx was also reduced when the combustion was conducted at low oxygen concentration. Introducing the high temperature $\left(\sim 1000^{\circ} \mathrm{C}\right)$ steam could decrease the NOx emission. As decreasing the air ratio, the flame was enlarged and flameless oxidation was observed. Under the low NOx combustion condition, uniform distribution of temperature and chemical species were confirmed.

Key Words : High Temperature Air Combustion, Ultra Low NOx Emission, Flameless Oxidation, Uniform Distribution
\end{abstract}

1. 序

高温空気燃焼は高効率で低環境負荷の燃焼技術として知 られており、鉄鋼関係の工業炉を中心として実用化が進め られ、さらに他の用途八の展開も検討されている。1 基礎的な面から高温空気燃焼を解明しようとする検討も進 められたが、2) 主としてガス燃料をを用いたものが多く、 液体燃料である石油燃料の検討例はほとんど知られていな かった。我々はこれまで $10 \mathrm{~kW}$ 程度の燃焼量の小型燃焼評 価装置を用い、基礎的な面からの検討を進め、以下の点を 明らかにしてきた。3)すなわち石油燃狫においても高温空 気燃焼によりガスと同等の低NOX燃焼性を示す。高温空 気燃焼現象の解明を行い、低NOx燃烤を示す高温空気燃 烤条件では、温度分布や化学種分布が一様になる。希积力゙ スのNOx低減効果は $\mathrm{C} \mathrm{O}_{2}>\mathrm{N}_{2}>\mathrm{Ar}$ の順に大きく、こ れはこれらのガスの比熱の違いがもたらす断熱火炎温度の 違いとして説明できること。またこれら希釈ガスの違いに より火炎の色が、それそれれパープル、グリーン、輝炎およ び青炎と変化する。燃料油性状（蒸留性状、アロマ分含有 量）によらず低NOx燃焼であり、またフュエルNOxを 低滅する可能性もあることを明らかにしてきた。さらに実 用化を想定した石油燃料を用いた高温空気燃焼技術の開発 を進めるためには、燃焼量の大きな燃鈥炉での検討が必要

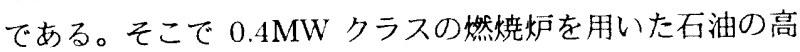
温空気燃烧の検討を開始した。

\section{2．実験装置と実験方法}

図 1 に石油の噴第燃焼が可能な高温空気燃焼炉の外観写 真およびバーナ部を示す。高温空気燃焼炉には、燃料、燃 焼用空気、抜熱用空気、アトマイズ用蒸気、高温水蒸気が 供給される。主要な機器は、燃焼炉本体（高温空気燃焼バ 一ナ、火炎状態を観測するための空、排ガスをサンプリン グする孔が設置)、燃料油夕ンク、蒸気過熱器、蒸気発生器 (貫流ボイラ)、および空気供給ユニット（ブロア、制御機器 駆動用コンプレッサー)、排気ファンである。また装置の運 転を制御するシステム、プロセスデー夕、排ガスデー夕、 温度デー夕を表示するシステム、温度分布を自動的に計測 するための制御システム、観測空に不活性ガスを供給する システムが付帯されている。

燃料油として、灯油、A 重油および C 重油の燃焼が可能 である。蒸気によりアトマイジングされた燃料油はバーナ センタ一部分から噴第される。燃焼量は 20〜 45 l/hr であ る。一次空気 $\left(40 \mathrm{~m}^{3}{ }_{\mathrm{N}} \mathrm{hr}\right)$ は燃料油噴射口の周りの噴射口 から供給される。燃料油噴射口および一次空気噴出し口の 上部にパイロットバーナが設置されている。燃焼用空気 $\left(200 \mathrm{~m}^{3}{ }_{\mathrm{N}} / \mathrm{hr} \sim 600 \mathrm{~m}^{3} \mathrm{~N} / \mathrm{hr}\right)$ は周囲に配置された 6 ヶ所の空 気供給/排ガス排出口から供給される。空気供給/排ガス排出 口の内部には八二力ム状の蓄熱体 $\left(144 \mathrm{~mm}^{\phi} \times 300 \mathrm{~mm}^{\mathrm{L}}\right)$ が設置されており、排ガスにより顕熱が蓄えられ、バルブ

[No.02-14] 日本機械学会第 12 回環境工学総合シンポジウム 2002 講演論文集 [2002.7.10～12・川崎 $]$ 

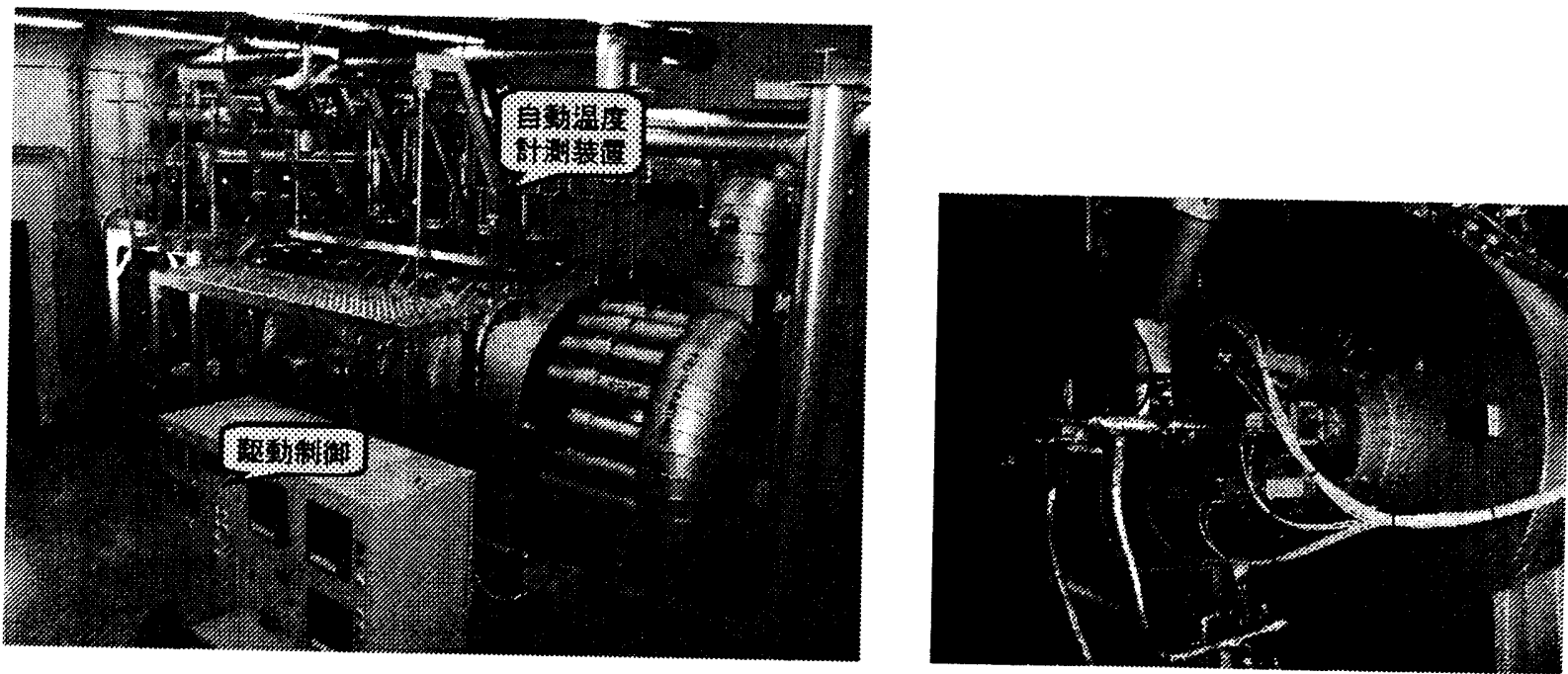

図 1 燃焼炉全体外観写真（左）およびバーナ部分（右）

の切り替えにより空気が供給され $1000^{\circ} \mathrm{C}$ 程度の高温空気 を燃焼炉内に導入する。6ケ所の空気供給/排ガス排出口の うち、4ヶ所は排気モードとなり、2 所が供給空気モー ドとなる。切り替えは任意に設定できるが、現在は 5 秒每 に切り替わり、連続した 2 ケ所から高温空気が供給される ようなバ夕ーンに設定されている。したがって1つの蓄熱 体では、20 秒連続して排気ガスにより蓄熱され、10 秒連 続で空気により放熱されることになる。蒸気過熱器から発 生した過熱蒸気は一次空気供給口の外側に設置された 2 ケ 所の噴出口から炉内に供給される。

\section{3。結果と考察}

(1) 火炎写真と NOx排出值

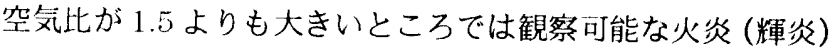
が観測されるが、空気比が 1.5 より小さくなると明らかな火 炎は観測されず、炉内全体でゆっくりとした燃焼が起こって おり “flameless oxidation”と呼ばれる燃焼状態が観測され た。図 2 は空気比を変えて $\mathrm{NOX}$ 排出値 $\left(\mathrm{O}_{2}=0 \%\right.$ 換算) をプ ロットしたものである。燃料は灯油であり燃焼量を 25 40 l/hrで変化し、炉内の温度は抜熱空気の量を調整して一定に

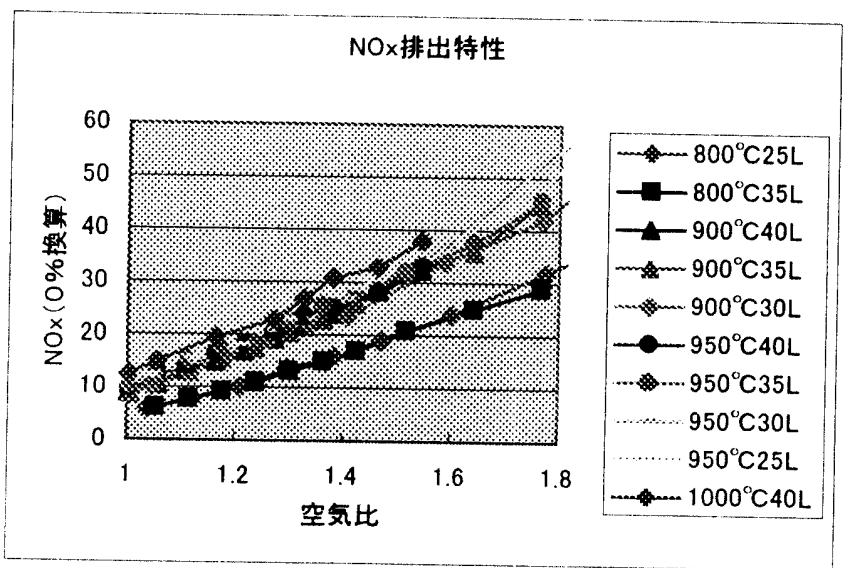

図 2 空気比と $\mathrm{NOx}$ 排出值

(炉内温度 800 $1000^{\circ} \mathrm{C}$ 、灯油流量 25〜 40l/hr)
保つて計測した。NOx排出值は空気比が低くなるにつれて急 激に減少し、理論空気量近辺で $10 \mathrm{ppm}$ 程度にまでなっている。 また温度が高くなるにつれて増加していることがわかる。灯 油の燃㜔量には依存せず、炉内の温度を一定に保つことによ り $\mathrm{NOx}$ 生成量が制御されていることがわかる。

(2) 高温水蒸気の投入効果

燃狫排ガス中には、燃料の未燃物、燃焼に関与しなかった 空気 (酸素、窒素)、空気完全燃燒により生成する炭酸ガス、 不完全燃焼により生成する一酸化炭素とともに、水蒸気も生 成する。生成した水蒸気は炭酸ガスと同様不活性ガスとして 燃烧を安定化させる。またその比熱は窒素よりも大きく、燃 焼火炎の断熱温度を下げることができる。また水蒸気を添加 することにより、より低酸素濃度の燃㮱場を形成することが できる。さらに水蒸気改質反応により、カーボンを水素と一 酸化炭素に変換する可能性もある。そこで高温の水蒸気の効 果を検討するため、貫流ボイラで発生した蒸気を蒸気過熱器 に送り、600〜 $1000^{\circ} \mathrm{C}$ 過熱して燃焼炉に投入し、水蒸気の 投入効果を検討した。以下、蒸気流量および蒸気温度が NOx 低減に及ぼす効果について述べる。

図 3 は蒸気流量と NOx排出值の関係を、空気比を変えて 測定した結果を示したものである。蒸気投入量が増加するに つれて低隇量は增加するが、リニアではないことがわかる。 特に低空気比の場合には、蒸気を投入しない場合の NOX排 出値も低いため、蒸気投入量を増加させてもそれほどの低減 効果は見られない。一方、空気比の高い場合には低減効果は かなり大きいことが明らかとなった。

次に蒸気温度が NOx生成に及ぼす影響について検討した 結果を述べる。図 4 は蒸気の温度を変化させて投入した時の NOx排出值を示す。蒸気温度が下がるにつれてわずかに NOx 排出値は低下しているか、あまり大きな効果はない。お そらく蒸気投入により部分的に火炎温度が低下したものと考 えられるが、投入した蒸気の流量から考えて、その効果はそ れほど大きくないものと思われる。 

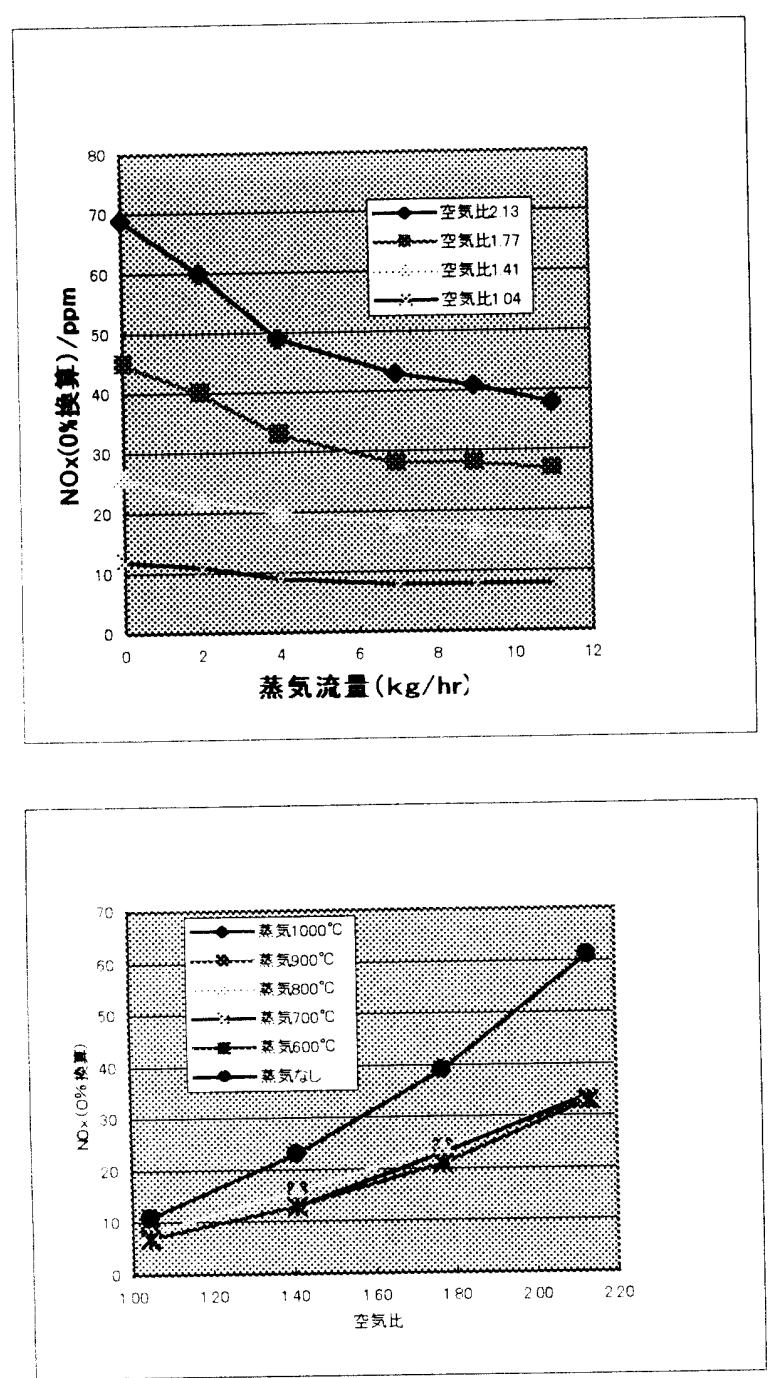

四 3 空気比の違いによる蒸気流量の NOx低減効果

図4 蒸気温度が NOx生成に及ぼす影響

（3）炉内温度分布計測

以上述べてきたように、極めて NOx排出値の低い高温空 気燃焼の現象が観測される場合には、明らかな火炎は観測さ れず、炉内が均一になっているものと予測される。そこで然 焼条件を変えて、炉内温度分布計測を行った。計測は 10 本の 熱電対を同時に駆動し、拔熱管の位置 $(500 \mathrm{~mm})$ から $50 \mathrm{~mm}$ ずつ中心に向って計測した。合計 110 点のデータを二次元炉 内温度分布として表現したが、ここで便宜上燃焼炉は上下対 称と考え、測定は 0 500 $\mathrm{mm}$ のみ行い、-50〜-500 の值は 50 500 の值をそのまま用いた。

図 5 は燃焼空気量の違いが炉内分布に及ぼす影響を検討し た結果である。灯油流量 301/hrに対して、(a)は燃烧空気量が $500 \mathrm{~m}^{3} \mathrm{~N} / \mathrm{hr}$ であり(b)は $300 \mathrm{~m}^{3} \mathrm{~N} / \mathrm{hr}$ の場合である。空気比は それぞれ 1.77 および 1.04 である。炉内温度は $900^{\circ} \mathrm{Cに}$ 調整 した。この図からわかるように、空気比が高い場合にはバナノズル先端から 500 1000 $\mathrm{mm}$ のところに高温部分があり、 これは火炎の輝炎の部分とほぼ一致している。一方空気比が 理論空気量に近い場合には、こうした高温部分の発生は見ら
れず、バーナの反対側が $100^{\circ} \mathrm{C}$ 程度高いゆるやかな温度分布 か観測された。このことから高温空気燃焼の条件になると、 温度分布が均一になり、NOxの低減か図られたと考えること ができる。

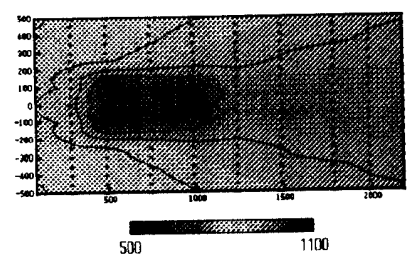

(a)

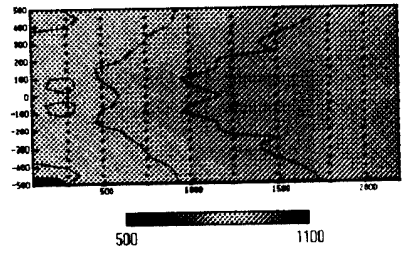

(b)
図 5 炬内温度二次元分布像（燃焼空気量の違い）

（a）燃焼空気量 $500 \mathrm{~m}^{3} \mathrm{~N} / \mathrm{hr}$ （b）燃焼空気量 $300 \mathrm{~m}^{3} \mathrm{~N} / \mathrm{hr}$ 灯油流量 $301 / \mathrm{hr}$ 、炉内温度 $900^{\circ} \mathrm{C}$

つぎに蒸気の投入効果を検討した結果を図 6 に示す。燃焼 空気量は $500 \mathrm{~m}^{3} \mathrm{~N} / \mathrm{hr}$ であり、(a)は蒝気を投入しない場合、(b) および(c)は $1000^{\circ} \mathrm{C}$ 高温水蒸気をそれぞれ $2 \mathrm{~kg} / \mathrm{hr} 、 11 \mathrm{~kg} / \mathrm{hr}$ 投入した場合の温度分布を示す。投入量が增えるにつれて炉 内の温度分布が均一になっていることがわかる。

一方空気比が低くもともと NOx生成も低い燃烤条件では 高温水蒸気を投入しても均一性はそれほど変化なかった。水 蒸気の投入効果は（2）で述べた NOx排出值の結果とよく 一致している。すなわち、空気比の高いところでは局所的な 高温部の生成が観測され NOxの排出值が高いか、空気比の 低い高温空気燃焼の領域になると、もともと温度分布は均であり NOX排出も抑えられているので、水蒸気を投入して もそれほど大きな効果をもたらすことはないものと考えられ る。 (a)

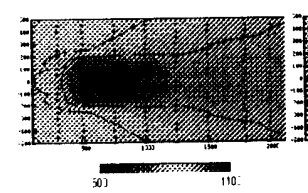

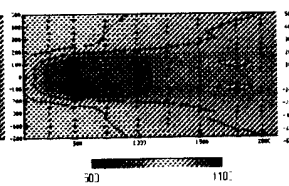

(b)

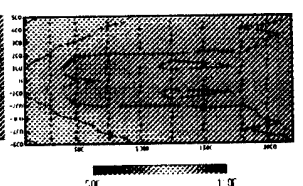

(c)
図 6 炉内温度二次元分布像（投入蒸気量の違い）

高温水蒸気量(a) $0 \mathrm{~kg} / \mathrm{hr} \quad$ (b) $2 \mathrm{~kg} / \mathrm{hr} \quad$ (c) $11 \mathrm{~kg} / \mathrm{hr}$ 燃焼空気量 $500 \mathrm{~m}^{3} \mathrm{~N} / \mathrm{hr}$ ）灯油流量 $30 \mathrm{l} / \mathrm{hr}$ 、炉内温度 $900^{\circ} \mathrm{C}$ 、 高温水蒸気温度 $1000^{\circ} \mathrm{C}$

\section{（4）燃料油種の違いの検討}

これまで述べてきた検討結果は、主として灯油を燃料とし た場合の検討結果であるが、A 重油の高温空気燃烤において もほぼ同等の結果が得られている。すなわち、空気比の高い ところでは灯油よりもやや強い輝炎が観測されたが、NOxの 排出値はほとんど同じかやや低い值であった。低空気比の高 温空気燃焼状態になると、灯油と同等に、明らかな火炎の観 測されない均一な燃焼状態となり灯油並みのサーマル $\mathrm{NOx}$ の排出値であった。A 重油は通常窒素分を平均して $200 \mathrm{ppm}$ 程度含んでおり、これらの化合物からフユエル NOxが20ppm 程度生成することが経験的に知られているが、高温空気燃焼 
ではこのフュエル NOxの低隇の可能性も見出している。現 在、その詳細について検討中である。また煤塵の発生も少な い可能性があるが、この点についても現在検討を進めている ところである。

4.まとめ

（1）空気比が高いところでは、バーナ一付近に輝炎の部分 が観測されるが、空気比の低いところになると、輝炎は ほとんど消えはっきりとした火炎の形が観測されない flameless oxidation の現象が観測された。

（2）NOx排出值は空気比が高くなるにつれて増加する。抜 熱空気量を調整して炉内温度を一定に保った場合、燃焼 量によらず同じ NOx排出值を示すことが明らかとなっ た。また炉内温度が高くなるにつれて増加する。

（3）高温水蒸気を投入した結果、NOx排出値は低減するこ とが明らかとなった。蒸気量が増加するにつれて、低減 量は增えるがリニアではない。また蒸気の温度には依存 しないことが明らかとなった。

（4）温度分布計測を行った結果、低酸素濃度の高温空気燃 烤条件になると局所的な高温部分は観測されないことか わかった。また蒸気投入によっても局所的高温部は消滅 し、均一に分布することが明らかとなった。

(5)灯油とA 重油では高温空気燃焼性に大きな違いはない。 すなわち A 重油を用いた場合には、空気比の高いところ では灯油燃狫の場合よりも強い輝炎の発光が観測される が、低空気比の燃焼条件では灯油とほぼ同様の結果が得 られた。

本研究は、経済産業省の補助金をもつて（財）石油産業活性 化センターの研究事業として行われたものである。

\section{参考文献}

1）高温空気燃焼技術フォーラム講演論文集、東京（2001）

2) Katsuki, M. and Hasegawa T., "The Science and Technology of Combustion in Highly Preheated Air. ", Proc. $27^{\text {th }}$ Symp. ( Int. ) on Combustion, Burgess A.R. and Dryer F.L., co-ed., The Combustion Institute, Pennsylvania, vol.2, pp. 3135-3146 ( 1998 ).

3) Shimo N., Itoh Y. and Yoshikawa K., " Development of Clean Combustion Technology for Many Kinds of Fuel Oil. “, Proc. $4^{\text {th }}$ Int. Symp. High Temperature Combustion and Gasification, 35 (2001). 